\title{
An epigrammatic analysis on open theism and its impact on classical Christianity
}

\begin{tabular}{|c|c|}
\hline \multicolumn{2}{|c|}{$\begin{array}{l}\text { Author: } \\
\text { Mark Pretorius }{ }^{1}\end{array}$} \\
\hline \multicolumn{2}{|c|}{$\begin{array}{l}\text { Affiliation: } \\
{ }^{1} \text { Department of Systematic } \\
\text { Theology and Christian } \\
\text { Ethics, University of Pretoria, } \\
\text { South Africa }\end{array}$} \\
\hline \multicolumn{2}{|c|}{$\begin{array}{l}\text { Note: } \\
\text { This article is based on the } \\
\text { research of extraordinary } \\
\text { lecturer Mark Pretorius } \\
\text { for his PhD dissertation, } \\
\text { entitled 'Exploring the } \\
\text { interaction between } \\
\text { theology and science, with } \\
\text { special reference to the } \\
\text { understanding of reality'. The } \\
\text { research is done under the } \\
\text { supervision of Prof. Dr Johan } \\
\text { Buitendag, Department of } \\
\text { Dogmatics and Christian } \\
\text { Ethics, Faculty of Theology, } \\
\text { University of Pretoria (2005). }\end{array}$} \\
\hline \multicolumn{2}{|c|}{$\begin{array}{l}\text { Correspondence to: } \\
\text { Mark Pretorius }\end{array}$} \\
\hline \multicolumn{2}{|c|}{$\begin{array}{l}\text { Email: } \\
\text { mark@sats.edu.za }\end{array}$} \\
\hline \multicolumn{2}{|c|}{$\begin{array}{l}\text { Postal address: } \\
\text { Private Bag X20, Hatfield } \\
0028 \text {, Pretoria, South Africa }\end{array}$} \\
\hline \multicolumn{2}{|c|}{$\begin{array}{l}\text { Dates: } \\
\text { Received: } 29 \text { July } 2013 \\
\text { Accepted: } 30 \text { July } 2013 \\
\text { Published: } 23 \text { Sept. } 2013\end{array}$} \\
\hline \multicolumn{2}{|c|}{$\begin{array}{l}\text { How to cite this article: } \\
\text { Pretorius, M., 2013, 'An } \\
\text { epigrammatic analysis on } \\
\text { open theism and its impact } \\
\text { on classical Christianity', } \\
\text { HTS Teologiese Studies/ } \\
\text { Theological Studies 69(1), } \\
\text { Art. \#2041, } 6 \text { pages. http:// } \\
\text { dx.doi.org/10.4102/hts. } \\
\text { v69i1.2041 }\end{array}$} \\
\hline \multicolumn{2}{|c|}{$\begin{array}{l}\text { Copyright: } \\
\text { (C) 2013. The Authors. } \\
\text { Licensee: AOSIS } \\
\text { OpenJournals. This work } \\
\text { is licensed under the } \\
\text { Creative Commons } \\
\text { Attribution License. }\end{array}$} \\
\hline \multicolumn{2}{|l|}{ Read online: } \\
\hline 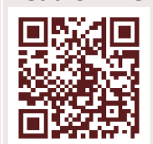 & $\begin{array}{l}\text { Scan this QR } \\
\text { code with your } \\
\text { smart phone or } \\
\text { mobile device } \\
\text { to read online. }\end{array}$ \\
\hline
\end{tabular}

Open theism is a theological position taken by a number of scholars and deals with human free will and its relationship to God, including the nature of the future. This brief article explores this relationship and challenges the tenets of open theism by arguing that it is a flawed system. The major thrust of the article asks two questions: Firstly, are the views of open theism consistent with God's divine attributes, namely all-knowing and all-powerful. Secondly, how should Christians relate their beliefs to a particular Zeitgeist?

\section{Introduction}

Over the centuries, Christians have held several opinions on how they should relate their Christian beliefs to the Zeitgeist, or spirit of the times, in this case, the views held by open theism. Some contend, according to Erickson (2002:63-64), that it is not only what one believes but also how one expresses it which must be preserved. In contrast, there are those who believe that, unless one preserves the content of Christianity, one is no longer dealing with what could be termed Christianity (see Erickson 2002:64). Although the latter group is similar to the first, there is a difference, as shall be shown.

The first group believes that the form of conception or expression of the Christian message can be adapted to suit modern times and situations (see Klassen 2005). Just as the Bible can be translated into many different languages without changing what it says so its message can be expressed in many different cultural forms without losing the essential meaning of the original. As such, one can bring forth its message in various time periods, using ways of thinking current at those times, without losing any of the essentials within the message. Regarding this premise, Pinnock (1989:27) reasons: 'Just as Augustine came to terms with ancient Greek thinking, so we are making peace with the culture of modernity.' Pinnock (2001) is also on record as saying the following:

As an open theist, I am interested in such authors as Hegel, Pierre Teilhard de Chardin, and Whitehead, because they make room in their thinking for ideas like change incarnation and divine suffering ... (p. 142)

However, these arguments are rightly disputed by Erickson (2001:129) who contends that one must rather find the essential meaning underlying all particular expressions of a biblical teaching. This, in his view, would simply be good hermeneutical practice.

This leads one to the contentious issue of world views. Whether one knows it or not, each person has a worldview. These worldviews tend to function as interpretive conceptual schemes, as upheld by Nash (1992:33), to explain how people view reality and why they often think and act in the way they do (see Cornish 2005). Unfortunately, competing worldviews often conflict with one another. Generally, according to Nash (1992:34), '[t]hese clashes may be as innocuous as a simple argument between people or may lead to a war between nations.' Consequently, it is important to recognise that competing world-views are the fundamental cause of disagreements and can often lead to splitting organisations (see Charles 2002:109).

Therefore, one could consider worldviews as double-edged swords, as pointed out by Nash (1992:34). For instance, he (Nash 1992:34) expresses the following view: 'An inadequate conceptual scheme can hinder ones efforts to understand God, the world, and oneself. However, alternatively, the right conceptual scheme can certainly bring everything into focus.' Unfortunately, the choices amongst competing worldviews involve several complex questions, making it difficult to be sure which criteria or tests one should use in choosing amongst worldviews. What follows now is a brief attempt to address these questions and to come to at least some reasonable answer as to the difficulty involved in dealing with open theism and how its proponents view the attributes of God, including how God experiences the world and deals practically with humankind.

\section{A brief introduction to open theism}

Open theism, also called openness or the open view and occasionally referred to as neotheism (see Geisler \& House 2001), is a theological position dealing with human free will and its 
relationship to God, including the nature of the future. It is the teaching that, although God has granted humanity free will, there are certain conditions to acting with free will. In the view of proponents of open theism, for the will to be truly free, the future free-will choices that individuals may make are unknown to God ahead of time (see Boyd 1997, 2000; Hasker 2004; Pinnock 1994, 2001). The premise is that if God knows what a person is going to choose, it cannot constitute free choice. They further argue that, if God does know beforehand, there can be no alternative choice since the individual choice is already 'known', implying that the choice in question would not really be free. As expressed by Craig (1998:103-104), this way of thinking is steeped in Aristotelian philosophy. Augustine, as did Aristotle, implied in their writings that God cannot have future knowledge of events that have not yet materialised (see Adam \& Kreztmann 1983:3-12; Furley 2003:417).

There are thus two extreme views on open theism: The future is either knowable or it is not. Those who hold to the first choice argue that God knowingly limits his knowledge of future events and choices (see Boyd 2000:15). Others, however, like Sanders ([1998] 2007), take this statement further by arguing that the future, being non-existent, is not knowable, not even by God:

All the future that is undetermined by God (which includes all future free choices and actions), since it has not happened and therefore not real, cannot be an object of knowledge. This future, they say, is logically unknowable, and as such not even God can rightly be said to know what cannot in principle be known. (p. 198)

This leads one to the interesting question of whether God's providential plans will come to pass, especially since the second view infers that the future is unknowable to God.

\section{God and the future}

The first question one may ask regarding the unknowability of the future is: Do open theists then believe that God's eventual plans will not come to pass? According to Wellum (2002:263), for open theists, the answer is an unambiguous no! Rather, open theists contend that even though God does not have exhaustive knowledge of future contingents, he is still God. Wellum (2002:264) further declares that, according to them, given God's familiarity with present causal tendencies and his clear grasp of his own providential designs, God is almost sure on how the future will turn out even though the future remains open. In Wellum's view, the premise of open theism concerning this point is untenable.

\section{However, in defence of this idea, Rice (1985) explains:}

God's future thus resembles ours in that it is both definite and indefinite. But it differs greatly from ours in the extent to which it is definite. Since we are largely ignorant of the past and present, the future appears vastly indefinite to us. We know little of what will happen because we know and understand so little of what has already happened. God, in contrast, knows all that has happened. Therefore most of the future that appears vague and indefinite to us must be vividly clear to Him. (pp. 55-56)
Nonetheless, Wellum (2002:264) correctly states that, despite these arguments, one must add that, even after all the constraints are factored in, open theists must still admit that a God with only present knowledge must take risks. Clearly then, if God's decisions depend only on the responses of free-willed creatures, creating and governing such a world is certainly 'a risky business', as expressed by Hasker (1989:197). Regarding this risky business, one could consider the following examples where, according to Ware (2000:45), openness proponents claim that God learns and may even be taken by surprise by what develops in his relation with humans (cf. Pretorius 2007:150-176).

In Genesis 22:10-12, God halts Abraham at the last moment with his knife ready to be raised above Isaac's tethered body and says:

Do not stretch out your hand against the lad, and do nothing to him; for now I know that you fear God, since you have not withheld you son, your only son, from Me.

Commenting on this text and others (cf. Gn 6:6-7; Ex 13:17, 32:7-14; Is 5:4, 7; 38:1-5), Sanders first approvingly quotes Brueggemann (1982:187) who writes, 'God genuinely does not know ... The flow of the narrative accomplishes something in the awareness of God. He did not know. Now he knows.' Consequently, Sanders ([1998] 2007) explains:

If the test is genuine for both God and Abraham, then what is the reason for it? The answer is to be found in God's desire to bless all the nations of the earth (Gen. 12:3). God needs to know if Abraham is the sort of person on whom God can count for collaboration toward the fulfilment of the divine project. Will he be faithful? Or must God find someone else through whom to achieve his purpose? God has been faithful; will Abraham be faithful? Will God have to modify his plans with Abraham? In [Gn] 15:8 Abraham asked God for assurance. Now it is God seeking assurance from Abraham. (pp. 52-53)

Thus for Sanders, this account is illustrative of the implied idea that God does not know what free creatures will do until they act. For example, will Abraham obey God? In Sanders's view, unfortunately God does not know. However, because of the test, God learns here and now that Abraham will. Therefore, in Sanders's view, one robs the passage of its natural meaning, especially when it is stripped of the simple message contained in God's own words: 'For now I know' (Gn 22:12). For some, such as Geisler and House (2001:263), open theism is merely another version of Whitehead's (1861-1947) process theology (see Bowman 2006). By this is meant that, since God supposedly has no foreknowledge of future events as they unfold before him through our free will choices, he is always learning new things about us.

On this point, Sanders ([1998] 2007:52-53) further contends that earlier episodes in the Biblical narratives distinctly show that not only does God learn moment by moment as humans freely choose and act, but at times, events may even genuinely surprise God (see Pretorius 2007: 150-176) As a result, future free actions may not only be unknown by God, they may also be unanticipated. Accordingly, Sanders ([1988] 2007) therefore suggests that the first sin of the woman and man in the Garden of Eden would frame such a case. He writes: 
God, in freedom, establishes the context in which a loving and trusting relationship between Himself and the humans can develop. God expects that it will, and there is no reason to suspect, at this point in the narrative, that any other possibility will come about. A break in the relationship does not seem likely considering all the good that God has done. (pp. 45-46)

Yet for Sanders ([1998] 2007:46), 'the implausible, the totally unexpected happens' - Adam and Eve disobey God and sin! Furthermore, not only does God learn that the man and woman have sinned, Sanders further claims, but God is actually quite surprised by this event. Although God always knew that sin was possible, it was not probable, reasonable or expected that his human creatures would turn their backs on him. Thus, it is impossible to know how often this may have happened in unfolding human history. In this passage at least, as suggested by Saunders, one has a concrete example of where God's belief about the future, that is, what he thought would most likely occur, was conspicuously wrong. As a result, God is surprised and thus corrects his mistaken belief as he learns this truth that the man and woman have sinned.

Although Sanders provides many such examples, the most significant is one that holds central importance in Christian doctrine. For Sanders ([1998] 2007:100-101), it simply cannot be conclusive that God had known in advance that Christ would in fact choose to be crucified. Thus, Christ's decision to go to the cross was not made in eternity past, as accepted throughout Church history. Rather, it was only in the historic moment when, in prayer to the Father, Christ determined (then) to take this path. The fact that Jesus prays to the Father, '[i]f You are willing, let this cup pass from $\mathrm{Me}^{\prime}$ (Mt 26:39) is, in the view of Sanders, evidence that the future was open. The suggestion here is that Christ's death and the cross were not determined by fate.

The question now is: Is God a risk taker? In classical Arminianism, God creates a world in which He foreknows with complete accuracy and precision exactly what will occur in every moment of history (see Picirilli 2001). To add to this, Copleston (2003:262) states: 'God's act of knowledge are infinite and eternal, so all things are present to Him, even future events ...' However, for Sanders ([1998] 2007:196197), 'God is never caught off guard, never surprised by any event and never forced to make any ad hoc decisions. Where is the risk in this view?' Sanders ([1998] 2007:176) continues: 'Yet God remains a risk taker in the sense that God allows libertarian ${ }^{1}$ freedom and does not control what the creatures do with it.'

Thus for Sanders, there is a sense in which God takes a risk in his creation of the world, thus leading to a strict nondeterministic model of divine providence. Granting libertarian freedom is a sufficient and, of course, a necessary condition for genuine risk-taking, according to supporters of open theism (see Peterson \& Van Arragon 2004:216-217).
However, there is a sense in which the level of risk for the God of open theism is certainly greater, according to Ware (2000:48). He states that in all other Arminian or nondeterministic models, one can at least say that, before God created the world, he knew exactly what he was getting, so to speak. He could foresee just what would happen, and he knew every aspect of history and its outcome from the start (cf. Erickson 2006). Thus, Pretorius (2007:162) argues: 'Every detail of the future, including every future free creaturely choice and action, is foreknown by God with exact precision before $\mathrm{He}$ acts to bring the world into existence.' And importantly, in all of these other Arminian models, from all eternity, God had known with certainty that and precisely how he would reign victorious in the end in accomplishing all of his purposes and fulfilling all of his promises.

\section{God's infinity and God's omniscience}

In the view of Geisler and House (2001:26-270), both theists and open theists agree that God is infinite (without limits). However, God's knowledge is identical with his nature since he is a simple Being. Thus God must know according to his Being; therefore, God must know infinitely. To be limited in knowledge of the future is, however, not to know infinitely. Hence, God's infinite knowledge must include all future events. If it does not, then he would be limited in his knowledge.

They further argue that all effects pre-exist in their efficient cause since a cause cannot produce what it does not possess. It cannot give what it does not have. Essentially, argue Geisler and House (2001):

God is the First Cause of all that exists or will exist. Hence, the future - with all of its free actions - pre-exists in God. As such, by knowing Himself, God knows all future free actions. God knows Himself infallibly and eternally. Thus, He has infallible and eternal knowledge of all free actions that will ever occur. (p. 27)

Unfortunately, for the open theists, this understanding seems to elude their thinking, or they simply do not feel it is necessary to address this attribute of God.

Importantly then, argue Geisler and House (2001:27-28), one must not lose focus of the fact that reality includes both the actual and the possible. Only the impossible is not real whilst God's knowledge extends to all that is real. If it did not, they further argue, 'then He would not be all knowing, since there would be something that He did not know' (Geisler \& House 2001:27), one has to revert to the God of open theism. However, if God does know the possible as well as the actual, it would mean that God must know the future since the future is possible, not impossible. If it were impossible, it would never happen. Hence, God must know all that will actualise in the future, including all future free acts.

This unfortunately leaves one with the question of the problem of evil. This problem, according to Pyne and Spencer (2001:266), is perhaps the dominant question of modern theology. How can one believe in a good and sovereign God who has absolute knowledge of what the future holds, yet 
allows horrific evil? For open theists, this is an important question, which they take seriously. They also believe that they address this important question and problem more satisfactorily than do classical theists.

\section{Sin and God's foreknowledge}

Hasker (1989:191-201) argues at length that open theism handles the problem of sin far better than the traditional view. According to open theists, the problem originates from the original sin of Adam - a view with which most theists will agree. Furthermore, according to Hasker (1989:), God is a risk taker because of God's lack of control over human actions:

$[O]$ ne finds excellence in the vision of a creation which, wholly dependent every moment on the sustaining and energising power of its Creator, nevertheless contains beings which possess under God's un-programmed freedom, a creativity of their own; and if such a case may be made, then it will be possible to claim that the God of free will theism is indeed the being through which nothing greater can be conceived. (pp. 99-107)

Moreover, Boyd claims that the Bible was written from the perspective of a 'warfare worldview'. As he (Boyd 1997) describes it, this worldview:

... is predicated on the assumption that divine goodness does not completely control or in any sense will evil; rather, good and evil are at war with each other. This assumption obviously entails that God is not now exercising exhaustive, meticulous control over the world. In this worldview, God must work with, and battle against, other created beings. While none of these beings can ever match God's own power, each has some degree of genuine influence within the cosmos. In other words, a warfare worldview is inherently pluralistic. There is no single, all-determinative divine will that coercively steers all things, and hence there is here no supposition that evil agents and events have a secret divine motive behind them. Therefore, one need not agonize over what ultimately good, transcendent divine purpose might be served by any particular evil event. (p. 20)

Unfortunately, statements such as the above imply, according to Pyne and Spencer (2001:267), that God is not able to prevent evil events from happening, a conclusion that does little to reinforce one's hope for the future. Free-will theists, however, scoff at this conclusion for they believe that God can intervene. As a result, they argue that God will surely defeat his enemies in the eschaton. As Boyd (1997:287) writes: 'hence the ability of any within the angelic or human society of God's creation to rebel freely against God shall someday come to an end.'

Mindful of Boyd's statements, Pyne and Spencer (2001) rightly state:

If open theists believe that God can intervene to prevent tragedies of human evil or for that matter, natural disasters, they have in no way escaped the traditional problem of evil. (p. 268)

\section{The diminished God of open theism}

As previously mentioned, some refer to the God of open theism as a God who takes risks. For example, Boyd (2000) suggests that taking responsible risks is a virtue and is thus appropriate for God:
Everyone who is psychologically healthy knows it is good to risk loving another person, for example. You may, of course, get hurt, for people are free agents. But the risk-free alternatives of not loving or of trying to control another person, is evidence of insecurity and weakness, if not sickness. Why should we abandon this insight when we think about God, especially since Scripture clearly depicts God as sometimes taking risks? (pp. $57-58)$

Boyd (2000) further suggests that:

if God is truly 'above' taking risks, then, we must accept that things such as sin, child mutilations, and people going to hell are all in accordance with God's will. (p. 58)

Though some affirm this, says Boyd (2000:58), most Christians '... reject it in horror. Clearly, God does not always get His way, but because God is wise, God's risks are always "worth it".' $^{\prime \prime}$

In a rebuff of this view, Ware (2000:50) correctly asks: 'Where in Scripture one sees God taking such risk?' From the examples presented, it seems clear from an openness perspective that God took a big risk simply in giving humans libertarian freedom. Although God wanted them to use their freedom to love and obey him, God knew such a capacity could be used for evil, destructive purposes. When Adam and Eve first sinned, it showed just how big the risk was that God took. Although he fully expected them to obey, they failed the test and brought the beginnings of extensive human sin into the world. This risk is all the more amazing when one realises that God would have known that his holiness would require sin's penalty to be paid.

As stated in the beginning, the open theism view needs to be tested as to its viability as a theistic worldview. According to Nash (1992:26), the criteria set forth for a well-rounded worldview includes beliefs in at least five major areas: God, reality, knowledge, morality and humankind. The question is: How does the open theism worldview compare with these criteria?

The following are the basic tenets of open theism as presented by Pretorius (2007:173-174). It is with these presuppositions that open theists approach the Bible and interpret it:

- God has no foreknowledge of future events: Open theists present two views here. Either God does not know the future since it does not exist or God purposely selects to not know it, even though it can be known.

- Humanity's free will is free in the libertarian sense: Humanity's free will is not restricted by humanity's propensity to $\sin$. In the view of open theists, though people sin, they still have the choice not to. Accordingly, they are able to make choices amongst many possibilities.

- The greatest attribute of God is love: Furthermore, open theists often advance this attribute of God above his other attributes. God is likened to one who cannot do harm but rather requires that all be saved, yet nevertheless mourns over their loss when they are not.

- God is a risk taker: Since God either limits his knowledge of future events or does not know, the idea is that God is 
a risk taker. This view stems from the idea that God deals with people who have free will. Accordingly, their freewill choices are unknowable to God.

- God is prone to make mistakes: Allowing that God does not know the future and since he is dealing with people who have free will, God can make mistakes in his dealings with people.

- God constantly learns as people make choices: Given that God is supposedly unaware of the future, he thus constantly learns as the future unfolds before him.

- God changes his mind: God can change his mind on issues depending on what he learns and what he discovers people do. Usually, God's change of mind is because of him being surprised by something he did not plan for or expect.

Unfortunately, open theism presents a view of God contrary to classical and historic Christianity, which see God as omniscient and sovereign, that is, all knowing (see Ps 139:2-6; Is 40:13-14; $1 \mathrm{Jn} 3: 20 ; \mathrm{Hb} 4: 13$ ) and unchanging (see Ps 102:2527; $\mathrm{Hb} 1: 10-12 ; 13: 8 ;$ Jm 1:7).

\section{Conclusion}

In concluding this study of open theism and its failure as a Biblically legitimate view, one would do well to consider two questions that have been in the foreground throughout this epigrammatic analysis. Firstly, can the teachings of God's foreknowledge and determination of the future be accounted for in open theism? And secondly, do any of these teachings require that one affirm specifically God's exhaustive knowledge of the future?

Firstly, one cannot fail to notice the specificity and exactness as well as the breadth and variety of God's knowledge and the prediction of many future items recorded throughout the Bible. God knows in advance every word that one speaks before it is even spoken (Ps 139:1-4). God predicts the names of certain individuals long before they are born as well as places in specific kingdoms that are yet in the future (Is 44:7; Lk 7:28; Ps 147:5; 1 Jn 3:20; 21:17). He declares how many kings will come at some future time, what alliances will be made and the effect of these on other nations and on Israel. He further knows how long government structures will be in place with precise accuracy, including the times and dates of events, which are far too many to mention here (Lv 26:33-38; Is $46: 9-10)$.

Secondly, one can notice how often that which was predicted, prophesied and determined by God have come to pass even though it involved the free will of people. To make this point more forcefully, one needs to ask: For a prophecy to be fulfilled, it may require that certain people are predestined to follow a certain path and act on certain issues. Does this not then require that God knows in advance what they are going to do since prophecy is words from people who have been inspired by God's Spirit? Doubtless, one will realise that the vast majority of predictions, if not all, have come to pass. This will surely give one an idea of how much God knows of all the free choices, decisions, actions and contingencies relating to the totality of the future, both near and far, that are known by God.

Despite the many expressions of hope put forth in open theism that God will surely and certainly fulfil his purpose in the end (see Sanders [1998] 2007:42), it must be seen, according to Ware (2000:51), just how significant this sense of risk is that God accepts when he chooses to create the kind of world that, according to open theism, he has created. The fact is: The God of open theism brings into existence a kind of world in which he exercises largely a power of love and persuasion towards his volitional creatures. All their free decisions, unknown in advance by him, have the potential of either advancing or violating his purposes. Thus, the success of God's purposes rests significantly in 'others' hands'. Consequently, at this very moment, according to open theism, not even God knows whether his purposes will be fulfilled. Unfortunately, the God of open theism truly is the God who takes risks.

\section{Acknowledgements Competing interests}

The author declares that he has no financial or personal relationship(s) that may have inappropriately influenced him in writing this article.

\section{References}

Adam, M.M. \& Kreztmann, N. (eds.), 1983, Predestination, God's foreknowledge, and future contingents, Hackett Publishing, Indianapolis, IN. (HPC Classic Series, William of Ockam)

Basinger, D., 1996, The case for free will theism, Intervarsity Press, Downers Grove, IL. Bowman, D., 2006, Handbook of process theology, Chalice Press, St. Louis, MO.

Boyd, G., 1997, God at war: The Bible and spiritual conflict, Intervarsity Press, Downers Grove, IL.

Boyd, G., 2000, God of the possible, Baker Books, Grand Rapids, MI.

Brueggemann, W., 1982, Genesis, John Knox, Atlanta, GA.

Charles, J.D., 2002, The unformed conscience of evangelicalism: Recovering the church's moral vision, Intervarsity Press, Downers Grove, IL.

Copleston, F., 2003, Medieval philosophy, Continuum International Publishing Group, London.

Cornish, R.W., 2005, 5 Minute apologist: Maximum truth in minimum time, NavPress, Colorado Springs, CO

Craig, W.L., 1998, The problem of divine foreknowledge and future contingents from Aristotle to Suarez, Brill Publishers, Leiden.

Erickson, M.J., 2001, Christian theology, Baker Books, Grand Rapids, MI.

Erickson, M.J., 2002, The postmodern world: Discerning the times and the spirit of our age, Crossway Books, Wheaton, IL.

Erickson, M.J., 2006, What does God know and when does He know it? The current controversy over divine foreknowledge, Zondervan, Grand Rapids, MI.

Furley, D., 2003. From Aristotle to Augustine, Routledge, London. PMCid:PMC2172860

Geisler, N. \& House, H., 2001, The battle for God, Kregel Publications, Grand Rapids, $\mathrm{Ml}$.

Hasker, W., 1983, Metaphysics: Constructing a world view, Intervarsity Press, Downers Grove, IL.

Hasker, W., 1989, God, time, and knowledge, Cornell University Press, Ithaca, NY. Hasker, W., 2004, Providence, evil, and the openness of God, Routledge, London.

Klassen, R., 2005, 'Metaphorical theology: An evangelical appropriation', Quodlibet Journal 7(2), viewed 30 July 2013, from http://www.quodlibet.net/articles/ klassen-theololgy.shtml

Nash, R.H., 1992, Worldviews in conflict: Choosing Christianity in a world of ideas, Zondervan, Grand Rapids, MI.

Peterson, M.L. \& Van Arragon, R.J., 2004, Contemporary debates in philosophy of religion, Blackwell, Oxford.

Picirilli, R.E., 2001, 'An Arminian response to John Sanders's The God who risks: A Theology of providence', Journal of the Evangelical Theological Society 44, 471. 
Pretorius, M., 2007, 'Understanding reality: exploring the interaction between theology and science, with special reference to a theistic presupposition to
certain worldviews', PhD dissertation, Department of Systematic Theology and certain worldviews', PhD dissertation,
Christian Ethics, University of Pretoria.

Pinnock, C.H., 1989, 'From Augustine to Arminius: A pilgrimage in theology', in C.H. Pinnock (ed.), In the grace of God and the will of man: A case for Arminianism, pp. 15-30, Zondervan, Grand Rapids, MI.

Pinnock, C.H., 1994, The openness of God, InterVarsity Press, Downers Grove, IL. PMCid:PMC191034

Pinnock, C.H., 2001, Most moved Mover: A theology of God's openness, Paternoster, Carlisle.
Pyne, R.A. \& Spencer, S.R., 2001, 'A critique of free-will theism, Part One', Bibliotheca Sacra 158, 259-286.

Rice, R., 1985, God's foreknowledge and man's free will, Bethany House, Minneapolis, MN.

Sanders, J., [1998] 2007, The God who risks: A theology of providence, Intervarsity Press, Downers Grove, IL.

Ware, A.B., 2000, God's lesser glory: The diminished God of open theism, Crossway Books, Wheaton, IL.

Wellum, S., 2002, 'Divine sovereignty-omniscience, inerrancy, and open theism: An evaluation', Journal of the Evangelical Theological Society 45(2), 257-277. 